\title{
Minutifloroside, a New Bis-Iridoid Glucoside with Antifungal and Antioxidant Activities and Other Constituents from Palicourea minutiflora
}

\author{
Vagner M. de Moura, ${ }^{a}$ Marcos A. S. Ribeiro, ${ }^{a}$ José G. S. Corrêa, ${ }^{a}$ Matheus A. Peixoto, ${ }^{a}$ \\ Gredson K. Souza, ${ }^{a}$ Damila Morais, ${ }^{b}$ Patrícia S. Bonfim-Mendonça, ${ }^{c}$ Terezinha I. E. Svidzinski, ${ }^{c}$ \\ Armando M. Pomini, ${ }^{\oplus a}$ Eduardo C. Meurer ${ }^{d}$ and Silvana M. O. Santin ${ }^{\circledR} * a$ \\ ${ }^{a}$ Departamento de Química, Universidade Estadual de Maringá, Avenida Colombo, 5790, \\ 87020-900 Maringá-PR, Brazil \\ ${ }^{b}$ Laboratório ThoMSon de Espectroscopia de Massas, Instituto de Química, Unicamp, \\ 13083-970 Campinas-SP, Brazil \\ 'Departamento de Análises Clínicas e Biomedicina, Universidade Estadual de Maringá, \\ Avenida Colombo, 5790, 87020-900 Maringá-PR, Brazil \\ ${ }^{d}$ Laboratório FENN de Espectrometria de Massas, Universidade Federal do Paraná, \\ 86900-000 Jandaia do Sul-PR, Brazil
}

\begin{abstract}
A new bis-iridoid glucoside minutifloroside (1) was isolated from Palicourea minutiflora, together with asperuloside, (-)-epicatechin, catechin, quercetin, rutin, ursolic acid, oleanolic acid, daucosterol and two monoterpenic indole alkaloids strictosidinic acid and vincosamine. Structural characterization of the compounds was established on their spectral data basis, mainly mass spectrometry (MS) and 1D and 2D nuclear magnetic resonance (NMR). The bis-iridoid showed high activity against Candida albicans strain and antioxidant activity.
\end{abstract}

Keywords: Palicourea minutiflora, Rubiaceae, bis-iridoid, alkaloids, antifungal activity

\section{Introduction}

Iridoids are monoterpenoids found in plenty of plants families and are present in a number of folk medicinal species. ${ }^{1,2}$ These bioactive metabolites were considered chemotaxonomic markers in the Rubiaceae family and exhibit remarkable biological and pharmacological properties such as neuroprotective, antitumor, antiinflammatory, antiviral, antibacterial, antifungal, antioxidant, antiprotozoal and antiallergic. ${ }^{3,4}$

The presence of dimer iridoids was found in species of Rubiaceae, mainly those belonging to the genus Saprosma, Paederia, Mussaenda, Lasianthus, Randia and Asperula. ${ }^{5}$

The genus Palicourea (Rubiaceae) is taxonomically complex and previous phytochemical studies demonstrate the remarkable presence of quinolinic and monoterpenoid indole alkaloids, ${ }^{6-8}$ flavonoids, ${ }^{9}$ coumarins ${ }^{10}$ and terpenoids. ${ }^{11}$

Therefore, as part of the investigative efforts to find compounds from Rubiaceae of the Northeastern Brazil flora, this work reports the first chemical study of aerial parts from

*e-mail: smoliveira@uem.br
Palicourea minutiflora, endemic species of Atlantic Forest from Brazil. The $\mathrm{MeOH}$ extract was investigated resulting in the isolation and structural elucidation of a new bisiridoid glucoside, minutifloroside (1), and the known iridoid asperuloside (2), the two monoterpenic indole alkaloids strictosidinic acid (3) and vincosamine (4), the flavonoids (-)-epicatechin, catechin, quercetin, and rutin, along with ursolic acid, oleanolic acid and daucosterol. The isolation of the vincosamine (4) and (-)-epicatechin has been reported for the first time in genus Palicourea. This paper deals with the isolation and structure elucidation of the new compound and the assessment of antifungal and antioxidant activities.

\section{Experimental}

General experimental procedures

Column chromatography (CC) was performed either over silica gel 60 (Merck, 70-230 mesh) or Sephadex LH-20 (Sigma-Aldrich). Analytical thin layer chromatography (TLC) was performed on precoated silica gel plates (TLC Silica gel $60 \mathrm{~F}_{254}$ from Merck) and the compounds were 
detected by UV light ( 250 and $366 \mathrm{~nm}$ ) and by spraying with chromogenic agents including $p$-anisaldehyde- $\mathrm{H}_{2} \mathrm{SO}_{4}$ and $\mathrm{H}_{2} \mathrm{SO}_{4}: \mathrm{MeOH}$ solution, followed by heating at $150^{\circ} \mathrm{C}$ or by spraying with Dragendorff solution.

Optical rotations were measured in $\mathrm{H}_{2} \mathrm{O}$ in a PerkinElmer 343 digital polarimeter at $20^{\circ} \mathrm{C}$ and $589 \mathrm{~nm}$, with an optical cell path of $10 \mathrm{~mm}$. High-resolution electrospray ionization Fourier transform mass spectrometry (ESI-FT-MS) data were performed using a Q-Exactive system (Thermo Fischer Scientific) constituted of a heated electrospray ionization (HESI-II) probe source and a hybrid mass analyzer, quadrupole-Orbitrap. The samples mass spectra were acquired in negative mode. The extract solution was injected by direct infusion with a flow rate of $10 \mu \mathrm{L} \mathrm{min}^{-1}$. The experimental parameters to ESI(-)-FT-MS analysis were as follows: spray voltage of $4.5 \mathrm{kV}$, capillary temperature of $300{ }^{\circ} \mathrm{C}$ and s-lens of $70 \mathrm{~V}$. For collision, it was applied high collision dissociation (HCD) of 10 and $20 \mathrm{eV}$. The Xcalibur 3.0.63 software (Thermo Fisher Scientific) was used to acquire and process the data. The exact mass from the $m / z$ of each ion was compared with theoretical $\mathrm{m} / \mathrm{z}$ to assign the molecular formula with an error less than 5 ppm. ESI(+)-MS data was acquired using a Premier XE triple quadrupole mass spectrometer (Waters Co.) running in the positive and negative ion mode. Major ESI(+)- and ESI(-)- S source parameters were as follow: capillary voltage of $2.0-3.5 \mathrm{kV}$, cone voltage of $10-45 \mathrm{~V}$ and the quadrupole was set to unitary resolution.

The nuclear magnetic resonance (NMR) spectra were recorded on a Varian-Mercury plus spectrometer operating at $300.06\left({ }^{1} \mathrm{H}\right)$ and at $75.45 \mathrm{MHz}\left({ }^{13} \mathrm{C}\right)$, respectively, and $\mathrm{D}_{2} \mathrm{O}$ as solvent.

\section{Plant material}

The aerial parts (leaves and branches) of P. minutiflora were collected in January 2014, at the Reserva Particular do Patrimônio Natural Serra Bonita (Camacan, Bahia State, Northeast of Brazil, geographical coordinates $15^{\circ} 23^{\prime} 30^{\prime}$ 'S; 39॰33'55”W). Voucher specimens (No. 141.214) were deposited at the Centro de Pesquisa do Cacau (CEPEC) and identified by Dr A. M. Amorim (Universidade Estadual de Santa Cruz) and authenticated by C. M. Taylor (Missouri Botanical Garden, MO).

\section{Extraction and isolation}

Dried powdered aerial parts $(600.0 \mathrm{~g})$ were extracted by maceration with $\mathrm{MeOH}$ at room temperature and concentrated under vacuum to yield $85.3 \mathrm{~g}$ of $\mathrm{MeOH}$ crude extract. Part of $\mathrm{MeOH}$ crude extract ( $10.0 \mathrm{~g})$ was dissolved in a mixture of $\mathrm{MeOH}: \mathrm{H}_{2} \mathrm{O}(1: 1 \mathrm{v} / \mathrm{v})$ and then successively partitioned with different solvents to give $n$-hexane (HF, $0.96 \mathrm{~g}$ ), $\mathrm{CHCl}_{3}$ (CF, $0.12 \mathrm{~g}$ ), EtOAc (AcF, $3.95 \mathrm{~g}$ ) and the remaining hydromethanolic (HMF, $4.97 \mathrm{~g}$ ) fractions.

The HMF fraction $(3.0 \mathrm{~g})$ was subjected to column chromatography on Sephadex LH-20, using $\mathrm{MeOH}$ as eluent to obtain 201 fractions, which after TLC analysis were pooled into eight subfractions $\left(\mathrm{HMF}_{1}-\mathrm{HMF}_{8}\right)$. $\mathrm{HMF}_{7}$ was also submitted to successive Sephadex LH-20 columns, by elution with $\mathrm{MeOH}$ leading to the isolation of compound $\mathbf{3}$ (16.1 mg). The subfraction $\mathrm{HMF}_{8}(521.5 \mathrm{mg}$ ) was applied to a Sephadex LH-20 column eluted with $\mathrm{MeOH}$ yielding 7 subfractions $\left(\mathrm{HMF}_{8.1}-\mathrm{HMF}_{8.7}\right)$. From fraction $\mathrm{HMF}_{8.2}$, it was obtained a precipitate, compound $\mathbf{1}$ $(2.0 \mathrm{mg})$ as amorphous brown solid.

The AcF fraction (3.05 g) was chromatographed on a Sephadex LH-20 column eluted with $\mathrm{MeOH}$ to give 255 fractions, which were grouped into 12 fractions after TLC analysis $\left(\mathrm{AcF}_{1}-\mathrm{AcF}_{12}\right) . \mathrm{AcF}_{1}(310.5 \mathrm{mg})$ was submitted to CC over silica gel 60 (70-230 mesh) and eluted with a gradient of $\mathrm{CHCl}_{3}: \mathrm{MeOH}$ yielding 7 subfractions $\left(\mathrm{AcF}_{1.1}-\mathrm{AcF}_{1.7}\right)$. From $\mathrm{AcF}_{1.6}$ it was obtained the quercetin (5.6 mg). The fraction $\mathrm{AcF}_{3}(219.2 \mathrm{mg}$ ) was submitted to purification on preparative $\mathrm{TLC}\left(\mathrm{CHCl}_{3}: \mathrm{MeOH}: \mathrm{H}_{2} \mathrm{O}, 7: 2: 1\right)$ to afford compound $2(6.2 \mathrm{mg})$. The $\mathrm{AcF}_{5}$ and $\mathrm{AcF}_{6}$ fractions (496.9 and $691.6 \mathrm{mg}$ ) were subjected on Sephadex LH-20 column eluted with $\mathrm{MeOH}$ to give 99 and 98 fractions each. The fractions were combined based on their TLC profile into 7 subfractions, respectively $\left(\mathrm{AcF}_{5.1-7}\right.$ and $\left.\mathrm{AcF}_{6.1-7}\right)$. Subfractions $\mathrm{AcF}_{5.3}$ and $\mathrm{AcF}_{6.5}$ showed precipitates, which were washed with $\mathrm{CHCl}_{3}$ and provided the flavonoids (-)-epicatechin $(5.5 \mathrm{mg})$, catechin $(2.0 \mathrm{mg})$ and rutin $(12.0 \mathrm{mg})$. Subfraction $\mathrm{AcF}_{6.7}(114.3 \mathrm{mg})$ was analyzed by preparative TLC $\left(\mathrm{CHCl}_{3}: \mathrm{MeOH}: \mathrm{H}_{2} \mathrm{O}, 6: 3: 1\right)$ and this procedure isolated the compound $4(6.3 \mathrm{mg})$.

The HF fraction $(0.96 \mathrm{~g})$ was fractionated by CC over silica gel eluted with $n$-hexane and mixtures of $n$-hexane/ EtOAc in order of increasing polarity (Hex, Hex:EtOAc $10-90 \%)$ providing the steroid daucosterol (15.2 $\mathrm{mg}$ ).

\section{Antifungal assay}

For susceptibility testing, we used the broth microdilution method according to the standards of the Clinical and Laboratory Standards Institute (M27-A3), ${ }^{12}$ with some modifications for natural products. ${ }^{13}$ The experiment was performed with standard strains: Candida albicans (ATCC 90028) and C. glabrata (ATCC 90030). The final cellular density of the yeast was adjusted to $0.5-5 \times 10^{3}$ colony-forming units $(\mathrm{CFU}) \mathrm{mL}^{-1}$ in RPMI (Roswell Park Memorial Institute, Gibco) with L-glutamine 
(without sodium bicarbonate) and $0.165 \mathrm{M} 3-(\mathrm{N}$-morpholino) propanesulfonic acid ( $\mathrm{pH}$ 7.2). The test was performed in flat-bottom 96-well microtiter plates (Techno Plastic Products, Switzerland). For the assay with compound 1, we tested concentrations of 1250 to $9.765 \mu \mathrm{g} \mathrm{mL}-1$ and fluconazole (Sigma) was used as reference antifungal drug. The plates were incubated at $35{ }^{\circ} \mathrm{C}$ for $48 \mathrm{~h}$. The minimum inhibitory concentration (MIC) of compound $\mathbf{1}$ was considered the lowest concentration at which no fungal growth was evident, by visual reading.

\section{Antioxidant assay}

The radical scavenging capacity of the bis-iridoid (1) was investigated from their ability to reduce the radical 2,2-diphenyl-1-picrylhydrazyl (DPPH*) by TLC bioautography analysis. ${ }^{14}$ The experiment was performed with Macherey-Nagel precoated silica gel 60 F254 plates (Düren, Germany) as the stationary phase and $\mathrm{CHCl}_{3}: \mathrm{MeOH}_{2} \mathrm{H}_{2} \mathrm{O}$ $(6: 3: 1)$ as the mobile phase. After application of the compound $1\left(1.0 \mathrm{mg} \mathrm{mL}^{-1}\right)$ and development, the plate was immersed for $2 \mathrm{~s}$ in $0.25 \%$ (m/v) DPPH' methanolic solution. The antiradical activity results appeared as yellow spots against the purple-blue background. The flavonoid rutin was used as positive control. ${ }^{15}$

\section{Minutifloroside (1)}

HRESIMS $m / z$, calcd. for $\mathrm{C}_{32} \mathrm{H}_{14} \mathrm{O}_{21}[\mathrm{M}-\mathrm{H}]^{-}:$761.2140, found: $761.2147 ;[\alpha]_{D}{ }^{20}=-65.0^{\circ}\left(c 0.002, \mathrm{H}_{2} \mathrm{O}\right) ;{ }^{1} \mathrm{H} \mathrm{NMR}$ (300.06 MHz, $\mathrm{D}_{2} \mathrm{O}$ ) and ${ }^{13} \mathrm{C} \mathrm{NMR}\left(75.45 \mathrm{MHz}, \mathrm{D}_{2} \mathrm{O}\right)$, see Table 1. Precursor ion of $\mathrm{m} / \mathrm{z}, 761.21472$ fragmented to the product ions of $\mathrm{m} / \mathrm{z} .717 .2242,419.1190,389.1084$, 227.0556, 209.0450, and 183.0657 (see Figures S8 and S9, Supplementary Information (SI) section).

\section{Results and Discussion}

Iridoids glucosides minutifloroside (1) and asperuloside (2), ${ }^{16}$ indole alkaloids strictosidinic acid $(\mathbf{3})^{17}$ and vincosamine $(\mathbf{4})^{18}$ (Figure 1), along with (-)-epicatechin, ${ }^{19}$ catechin, ${ }^{20}$ quercetin, ${ }^{21}$ rutin, ${ }^{22}$ ursolic acid, ${ }^{23}$ oleanolic acid, ${ }^{24}$ and daucosterol, ${ }^{25}$ were isolated from the aerial parts extract of Palicourea minutiflora. The structures of known compounds were identified and elucidated using a combination of spectroscopic techniques $\left({ }^{1} \mathrm{H},{ }^{13} \mathrm{C} \mathrm{NMR}\right.$ and $\left.2 \mathrm{D} \mathrm{NMR}\right)$ and by comparisons with literature data. ${ }^{16-25}$

The structure of the new compound $\mathbf{1}$ was elucidated by spectrometric methods, including $1 \mathrm{D}$ and 2D NMR experiments and HRESIMS.
Compound $\mathbf{1}$ was isolated as a brown amorphous powder, $[\alpha]_{D}{ }^{20}=-65.0^{\circ}\left(\mathrm{H}_{2} \mathrm{O}\right)$, and the molecular formula was assigned as $\mathrm{C}_{32} \mathrm{H}_{14} \mathrm{O}_{21}$, based on its negative ion HRESIMS, through the precursor ion peak of $m / z, 761.21472[\mathrm{M}-\mathrm{H}]^{-}$.

The MS/MS spectra (Supplementary Information Figures S8 and S9) for $m / z 761.21472$ presented four main pathways. The first two pathways proposed (Scheme 1) the formation of the ions of $m / z 717.2242\left(\left[\mathrm{M}-\mathrm{H}-\left(\mathrm{CO}_{2}\right)\right]^{-}\right)$ $\left(\mathrm{CO}_{2}, 43.9898\right)$ and of $m / z 419.1190\left(\left[\mathrm{M}-\mathrm{H}-\left(\mathrm{C}_{15} \mathrm{H}_{18} \mathrm{O}_{9}\right)\right]^{-}\right)$ $\left(\mathrm{C}_{15} \mathrm{H}_{18} \mathrm{O}_{9}, 342.0951\right)$, that were formed from the decarboxylation of the deprotonated molecule, and a hydroxyl group rearrangement, respectively. The hydroxyl group rearrangement was proposed as an analogous mechanism to dehydration reactions by eliminating a water molecule and forming double bond. ${ }^{26}$ The other two pathways (Scheme 2), that formed the ions of $m / z 389.1084$ $\left(\left[\mathrm{M}-\mathrm{H}-\left(\mathrm{C}_{16} \mathrm{H}_{20} \mathrm{O}_{10}\right)\right]^{-}\right)\left(\mathrm{C}_{16} \mathrm{H}_{20} \mathrm{O}_{10}, 372.1056\right)$ and of $\mathrm{m} / z$ $227.0556\left(\left[\mathrm{M}-\mathrm{H}-\left(\mathrm{C}_{22} \mathrm{H}_{30} \mathrm{O}_{15}\right)\right]^{-}\right)\left(\mathrm{C}_{22} \mathrm{H}_{30} \mathrm{O}_{15}, 534.1585\right)$, were proposed toward neutral loss of the molecule $\mathrm{C}_{16} \mathrm{H}_{20} \mathrm{O}_{10}$ by typical remote hydrogen rearrangement, ${ }^{26,27}$ and the formation of the ion $m / z 227.0556\left(\left[\mathrm{C}_{10} \mathrm{H}_{11} \mathrm{O}_{6}\right]^{-}\right)$ corresponding to regular profile observed in study of iridoid glycosides fragmentation forming epoxide moiety of the neutral molecule $\mathrm{C}_{22} \mathrm{H}_{30} \mathrm{O}_{15}$ (534.1585) (Scheme 2). ${ }^{28}$ It was also observed that the ion of $m / z 389.1084\left(\left[\mathrm{C}_{16} \mathrm{H}_{21} \mathrm{O}_{11}\right]^{-}\right)$ fragmented by water loss to the ion of $\mathrm{m} / z$ 371.0978. ${ }^{26,28}$ The fragment of $\mathrm{m} / \mathrm{z} 227.0556$ may be formed from the precursor ion and the product ion of $m / z 389.1084 .^{28,29}$ This ion presents several fragments, providing more information of the structure resulting in two possible ions pathways, one by its decarboxylation resulting in the ions of $\mathrm{m} / \mathrm{z} 183.0657$ $\left(\left[\mathrm{C}_{9} \mathrm{H}_{11} \mathrm{O}_{4}\right]^{-}\right)$and the other fragment of $\mathrm{m} / \mathrm{z}, 209.0450$ $\left(\left[\mathrm{C}_{10} \mathrm{H}_{9} \mathrm{O}_{5}\right]^{-}\right)$was formed by elimination of a water. ${ }^{28}$

The ${ }^{1} \mathrm{H}$ and ${ }^{13} \mathrm{C}$ NMR spectra indicated the presence of the signals of two distinct moieties of an iridoid glucoside structure and suggested this compound is a bis-iridoid glucoside which is hereafter referred to as units A and B (Table 1). The ${ }^{1} \mathrm{H}$ NMR spectrum showed signals at $\delta 7.66$ (brs, H-3), 4.99 (d, J 8.8 Hz, H-1), 4.88 (m, H-6), 6.03 (brs, H-7), 4.47 (d, J 15.9 Hz, H-10a), 4.27 (d, $J 15.9 \mathrm{~Hz}, \mathrm{H}-10 \mathrm{~b})$ of unit A, based on analysis of the heteronuclear multiple quantum correlation (HMQC), ${ }^{1} \mathrm{H}-{ }^{1} \mathrm{H}$ correlation spectroscopy (COSY) and heteronuclear multiple bond correlation (HMBC) spectra. Signals at $\delta 4.86$ in the ${ }^{1} \mathrm{H}$ NMR and at $\delta 101.9$ in the ${ }^{13} \mathrm{C} \mathrm{NMR}$ spectra stand for the terminal group of the sugar. In the nuclear Overhauser effect spectrum (NOESY), a signal at $\delta 2.66$ (H-9) correlated with 4.99 (H-1), 3.11 (H-5) and 4.88 (H-6) indicating that these bonds have the same cis-configuration. The moiety (unit A) was established by 
Table 1. NMR spectroscopic data (300.06 and $75.45 \mathrm{MHz}, \mathrm{D}_{2} \mathrm{O}$ ) for minutifloroside (1)

\begin{tabular}{|c|c|c|c|c|}
\hline Position & $\delta_{\mathrm{H}}($ mult., $J$ in $\mathrm{Hz})$ & $\delta_{\mathrm{C}}$ & COSY & HMBC \\
\hline \multicolumn{5}{|c|}{ Unit A } \\
\hline 1 & $4.99(\mathrm{~d}, 8.8)$ & 103.7 & 2.66 & - \\
\hline 3 & 7.66 (brs) & 157.6 & 3.11 & $43.6,103.7,110.5,175.9$ \\
\hline 4 & - & 110.5 & - & - \\
\hline 5 & $3.11(\mathrm{dd}, 6.5,6.5)$ & 43.6 & $2.66,7.66$ & $103.7,110.5,131.8$ \\
\hline 6 & $4.88(\mathrm{~m})$ & 77.0 & - & $131.8,152.2$ \\
\hline 7 & 6.03 (brs) & 131.8 & - & $43.6,47.3,77.0$ \\
\hline 8 & - & 152.2 & - & $47.3,63.1$ \\
\hline 9 & $2.66(\mathrm{dd}, 8.1,8.1)$ & 47.3 & $3.11,4.99$ & $77.0,103.7,131.8,152.2$ \\
\hline 10 & $4.47(\mathrm{~d}, 15.9)$ & 63.1 & - & $131.8,152.2$ \\
\hline & $4.27(\mathrm{~d}, 15.9)$ & & - & - \\
\hline 11 & - & 175.9 & - & - \\
\hline $1^{\prime}$ & $4.86^{\mathrm{a}}$ & 101.9 & 3.38 & 103.7 \\
\hline $2^{\prime}$ & $3.38^{\mathrm{a}}(\mathrm{m})$ & 75.8 & 4.86 & 78.6 \\
\hline $3^{\prime}$ & $3.51^{\mathrm{a}}(\mathrm{m})$ & 78.6 & - & 72.4 \\
\hline $4^{\prime}$ & $3.41^{\mathrm{a}}(\mathrm{m})$ & 72.4 & - & 79.0 \\
\hline 5 & $3.42^{\mathrm{a}}(\mathrm{m})$ & 79.0 & - & - \\
\hline 6 & $3.77^{\mathrm{a}}(\mathrm{m})$ & 63.8 & - & 66.4 \\
\hline \multicolumn{5}{|c|}{ Unit B } \\
\hline 1 & $5.26(\mathrm{~d}, 5.9)$ & 99.9 & 3.14 & $48.7,101.6,154.1$ \\
\hline 3 & 7.40 (brs) & 154.1 & 3.04 & $46.5,99.9,114.5$ \\
\hline 4 & - & 114.5 & - & - \\
\hline 5 & $3.04(\mathrm{~m})$ & 46.5 & $3.14,7.40$ & $\begin{array}{c}48.7,99.9,131.5,114.5 \\
154.1\end{array}$ \\
\hline 6 & $4.61(\mathrm{~m})$ & 83.4 & - & $83.4,48.7,62.4,83.4$ \\
\hline 7 & 5.84 (brs) & 131.5 & - & 62.4 \\
\hline 8 & - & 148.5 & - & 99.9 \\
\hline 9 & $3.14(\mathrm{~m})$ & 48.7 & $3.04,5.26$ & - \\
\hline 10 & $4.31-4.25(\mathrm{~d}, 15.0)$ & 62.4 & - & - \\
\hline 11 & - & 175.9 & - & $75.6,99.9$ \\
\hline $1 "$ & $4.79^{\mathrm{a}}$ & 101.6 & 3.33 & 78.7 \\
\hline $2 "$ & $3.38(\mathrm{~d}, 9.0$ and 8.0$)$ & 75.6 & 4.79 & 72.4 \\
\hline $3 "$ & $3.51^{\mathrm{a}}(\mathrm{m})$ & 78.7 & - & 79.1 \\
\hline $4 "$ & $3.41^{\mathrm{a}}(\mathrm{m})$ & 72.4 & - & - \\
\hline $5 "$ & $3.42^{\mathrm{a}}(\mathrm{m})$ & 79.1 & - & 72.4 \\
\hline $6 "$ & $4.02-3.70^{\mathrm{a}}(\mathrm{m})$ & 66.8 & - & - \\
\hline
\end{tabular}

${ }^{a}$ Overlapped signals. COSY: correlation spectroscopy; HMBC: heteronuclear multiple bond correlation.

comparing their spectroscopic data with those reported for deacetylasperulosidic acid. ${ }^{30}$

The remaining spectral data revealed a second iridoid unit (part B) of the new bis-iridoid. Signals at $\delta 7.40$ (brs, H-3), 5.26 (d, J 5.9 Hz, H-1), 4.61 (m, H-6), 5.84 (brs, H-7), 4.31 and 4.25 (d, $J 15.0, \mathrm{H}-10 \mathrm{a}, \mathrm{b})$. The terminal group of the sugar was revealed by signals at $\delta 4.79$ in the ${ }^{1} \mathrm{H}$ NMR and at $\delta 101.6$ in the ${ }^{13} \mathrm{C}$ NMR spectra. In the NOESY spectrum, a signal at $\delta 3.14$ (H-9) correlated with 5.29 (H-1) and 3.04 (H-5) indicating the cis-junction between the two rings and the $O$-glycosyl residue $\mathrm{C}$ - 1 " with a $\beta$ configuration. The ${ }^{1} \mathrm{H}$ and ${ }^{13} \mathrm{C}$ NMR data of the moiety indicated signals similar to those of scandoside, ${ }^{30}$ and further confirmed by the detailed analyses of ${ }^{1} \mathrm{H}-{ }^{1} \mathrm{H}$ COSY and HMBC spectra. Further proof of the linkage was obtained from the HMBC correlations between $\mathrm{H}-6$ ' at $\delta 3.77(\mathrm{~m})$ of the unit $\mathrm{A}$ and C-6" $\delta 66.8$ of precoated unit B, and by extensive analysis in mass (MS/MS) experiment.

The compound 1 was assayed for their antifungal activities against the yeasts $C$. albicans and C. glabrata by broth microdilution method. This compound exhibited the highest antifungal activity in C. albicans than $C$. glabrata species. The MIC was $9.765 \mu \mathrm{g} \mathrm{mL}^{-1}$ for $C$. albicans and killed at C. glabrata at $1250 \mu \mathrm{g} \mathrm{mL} \mathrm{L}^{-1}$. 


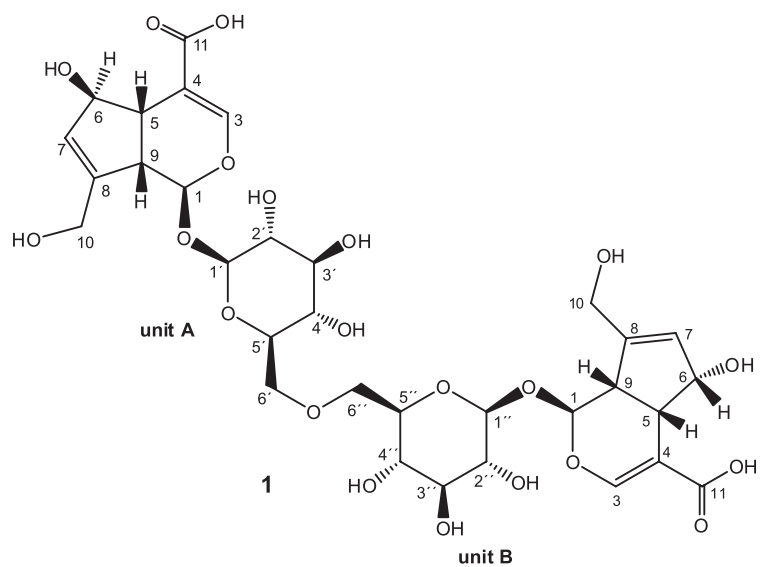

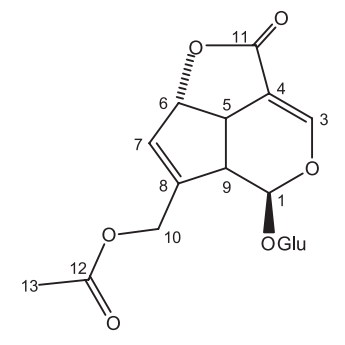

2

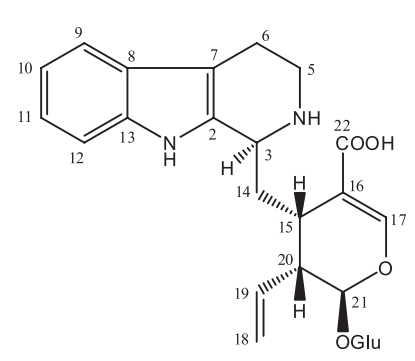

3

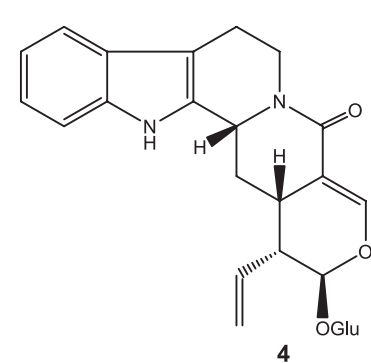

4

Figure 1. Chemical structure of compounds 1-4 isolated from aerial parts of Palicourea minutiflora.
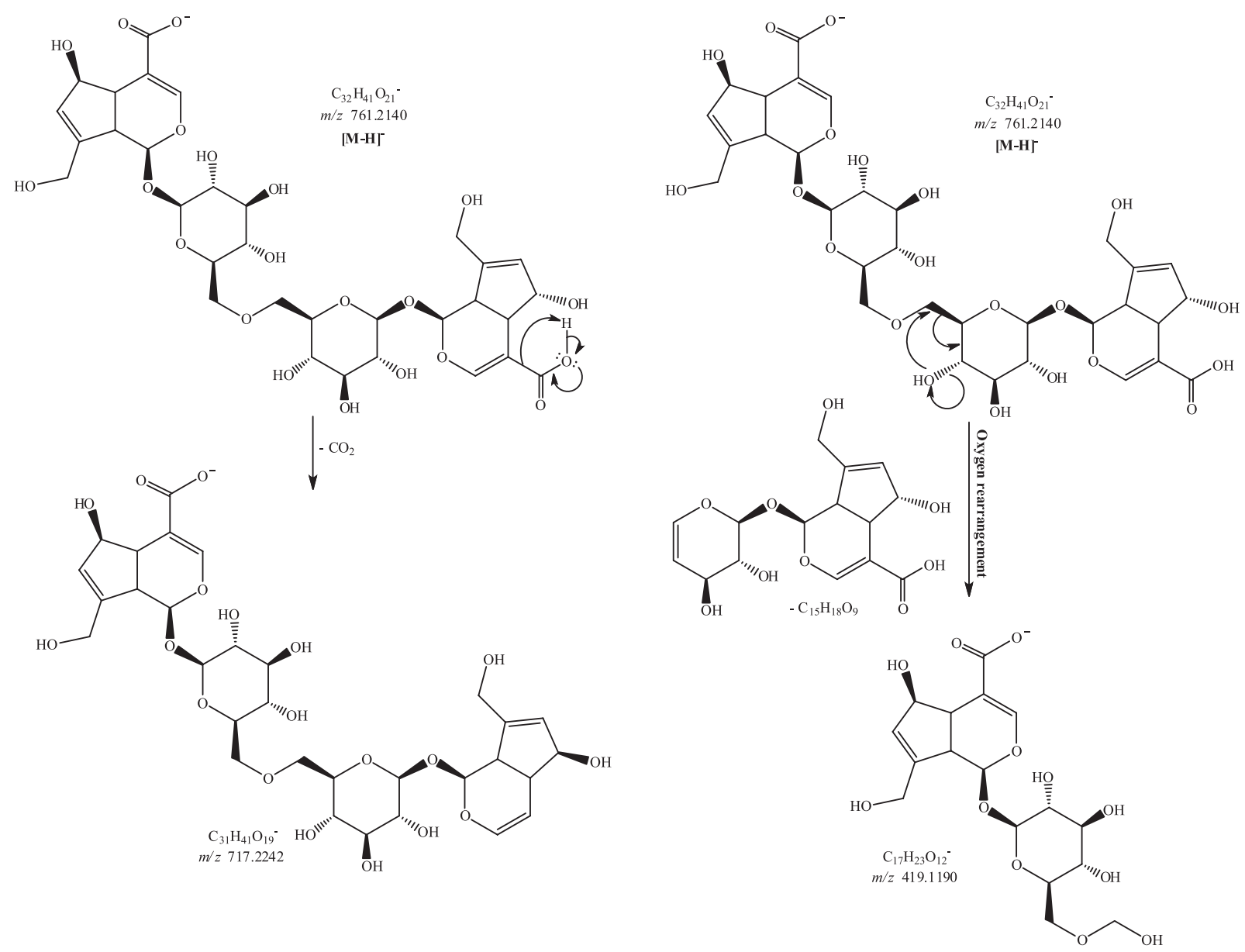

Scheme 1. Proposed fragmentation mechanism for precursor ion and two fragments for compound $\mathbf{1 .}$ 
<smiles>C[C@@H]1[C@@H](CO)O[C@H](O[C@@H]2OC=C(C(=O)O)[C@@H]3C2C(CO)=C[C@@H]3C)[C@H](O)[C@H]1O</smiles>

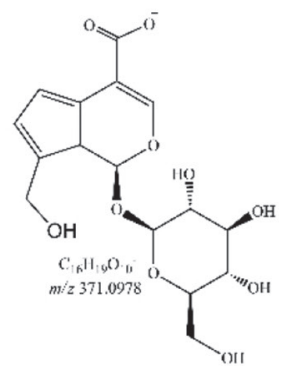

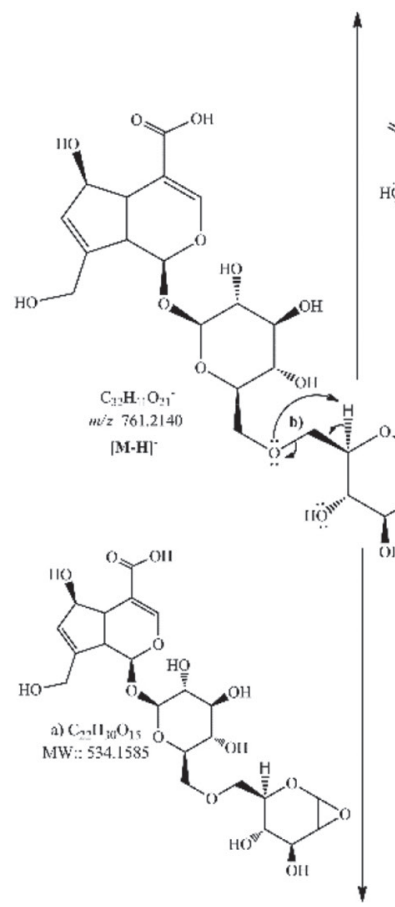<smiles>C=C1O[C@H](O[C@H]2OC=C(C(=O)O)[C@@H]3C2C(CO)=C[C@H]3C)[C@H](C)[C@H](O)[C@@H]1O</smiles>
(16) 37205

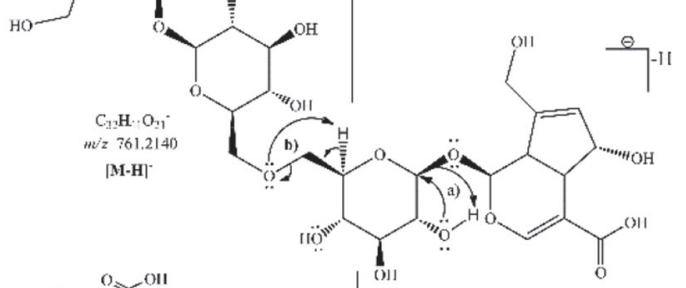

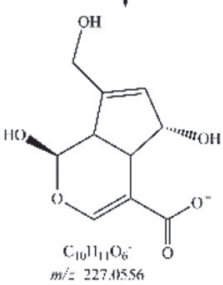

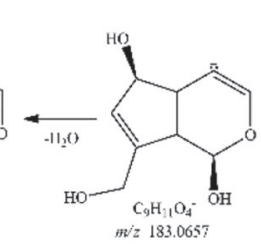
$m / 2183.0657$<smiles>C[C@H]1OC=C(C(=O)O)C2=CC=C(CO)C21</smiles>

Scheme 2. Proposed fragmentation mechanism for precursor ion and two fragments for compound $\mathbf{1 .}$

The capacity to scavenge $\mathrm{DPPH}^{\bullet}$ radical using TLC bioautography method was also carried out with compound $1 .{ }^{14}$ The antioxidant activity was positive for compound 1 at $1 \mathrm{mg} \mathrm{mL}^{-1}$ by visualization of a yellow spot against the purple background.

\section{Conclusions}

In summary, in this study two monoterpenic indole alkaloids, four flavonoids and three terpenoids were isolated from the methanolic extract from P. minutiflora Müll. Arg., including asperuloside and a novel bis-iridoid, minutifloroside. This bis-iridoid exhibited high antifungal activity against $C$. albicans and showed antioxidant capacity.

\section{Supplementary Information}

1D and 2D NMR spectra for compound $\mathbf{1}$ are available online free of charge at http://jbcs.sbq.org.br as a PDF file.

\section{Acknowledgments}

We acknowledge the Coordenação de Aperfeiçoamento de Nível Superior (CAPES) for financial support.

\section{References}

1. Berger, A.; Fasshuber, H.; Schinnerl, J.; Robien, W.; Brecker, L.; Valant-Vetschera, K.; J. Ethnopharmacol. 2011, 138, 756. 
2. Moreira, F. M.; Vieira, I. J. C.; Braz-Filho, R.; Am. J. Plant Sci. 2015, 6, 2612.

3. Dinda, B.; Debnath, S.; Banik, R.; Chem. Pharm. Bull. 2011, $59,803$.

4. Liu, Z.-H.; Hou, B.; Yang, L.; Ma, R.-J.; Li, J.-Y.; Hu, J.-M.; Zhou, J.; RSC Adv. 2017, 7, 24940.

5. Dinda, B.; Chowdhury, D. R.; Mohanta, B. C.; Chem. Pharm. Bull. 2009, 57, 765 .

6. Berger, A.; Tanuhadi, E.; Brecker, L.; Schinnerl, J.; ValantVetschera, K.; Phytochemistry 2017, 143, 124.

7. Dusman, L. T.; Jorge, T. M.; Souza, M. C.; Eberlin, M. N.; Meurer, E. C.; Bocca, C. C.; Basso, E. A.; Sarragioto, M. H.; J. Nat. Prod. 2004, 67, 1856.

8. Valverde, J.; Tameyo, G.; Hessen, M.; Phytochemistry 1999 , 52,1485

9. Rosa, E. A.; Silva, B. C.; Silva, F. M.; Tanaka, C. M. A.; Peratta, R. M.; Oliveira, C. M. A.; Kato, L.; Ferreira, H. D.; Silva, C. C.; Rev. Bras. Farmacogn. 2010, 20, 484.

10. El-Seedi, H. R.; Rev. Latinoam. Quim. 1999, 27, 13.

11. Bolzani, V. S.; Trevisan, L. M. C.; Young, C. M.; Rev. Latinoam. Quim. 1992, 22, 20.

12. CLSI; Approved Standard $3^{\text {rd }}$ Informational Supplement, M27-A3: Reference Method for Broth Dilution Antifungal Susceptibility Testing of Yeasts; CLSI: Wayne, PA, 2008.

13. Dalben-Dota, K. F.; Faria, M. G. I.; Bruschi, M. L.; Pelloso, S. M.; Lopes-Consolaro, E.; Svidzinski, T. I. E.; J. Altern. Complementary Med. 2010, 16, 285.

14. Simões-Pires, C. A.; Queiroz, E. F.; Henriques, A. T.; Hostettmann, K.; Phytochem. Anal. 2005, 16, 307.

15. Chapla, V. M.; Zeraik, M. L.; Cafeu, M. C.; Silva, G. H.; Cavalheiro, A. J.; Bolzani, V. S.; Young, M. C. M.; Pfenning, L. H.; Araujo, A. R.; J. Braz. Chem. Soc. 2018, 29, 1707.

16. Moura, V. M.; Santos, D. P.; Carvalho, J. E.; Foglio, M. A.; Quim. Nova 2006, 29, 452.
17. Arbain, D.; Putra, D. P.; Sargent, M. V.; Aust. J. Chem. 1993, 46, 977.

18. Erdelmeier, C. A. J.; Wright, A. D.; Orjala, J.; Baumgartner, B.; Rali, T.; Sticher, O.; Planta Med. 1991, 57, 149.

19. Tanaka, J. C.; Silva, C. C.; Dias Filho, B. P.; Nakamura, C. V.; Carvalho, J. E.; Foglio, M. A.; Quim. Nova 2005, 28, 834.

20. Lôbo, L. T.; Castro, K. C. F.; Arruda, M. S.; Silva, A. C.; Müller, A. H.; Arruda, M. S. P.; Santos, A. S.; Filho, A. P. S. S.; Quim. Nova 2008, 31, 493.

21. Scognamiglio, M.; D’Abrosca, B.; Esposito, A.; Fiorentino, A.; J. Anal. Methods Chem. 2015, DOI: 10.1155/2015/258570.

22. Selvaraj, K.; Chowdhury, R.; Bhattacharjee, C.; Int. J. Pharm. Pharm. Sci. 2013, 5, 743.

23. Rao, M. S.; Kumar, J. K.; Rao, P. S.; Tóth, G.; Simon, A.; Balázs, B.; Duddek, H.; Fitoterapia 1999, 70, 200.

24. Guvenalp, Z.; Ozbek, H.; Kuruuzum-Uz, A.; Kazaz, C.; Demirezer, L. O.; Turk. J. Chem. 2009, 33, 667.

25. Matida, A. K.; Rossi, A. K.; Blumental, E. E. A.; Schuquel, I. T. A.; Malheiros, A.; Vidotti, G. J.; An. Assoc. Bras. Quim. 1996, $45,147$.

26. Demarque, D. P.; Crotti, A. E. M.; Vessecchi, R.; Lopes, J. L. C.; Lopes, N. P.; Nat. Prod. Rep. 2016, 33, 432.

27. Kucharska, A. Z.; Fecka, I.; Molecules 2016, 21, 1157.

28. Heffels, P.; Muller, L.; Schieber, A.; Weber, F.; Food Res. Int. 2016, 100, 468.

29. Li, C.-M.; Zhang, X.-L.; Xue, X.-Y.; Zhang, F.-F.; Xu, Q.; Liang, X.-M.; Rapid Commun. Mass Spectrom. 2008, 22, 1954.

30. Tzakou, O.; Mylonas, P.; Vagias, C.; Petrakis, P. V.; Z. Naturforsch., C: J. Biosci. 2007, 62, 597.

Submitted: February 25, 2019 Published online: September 2, 2019 